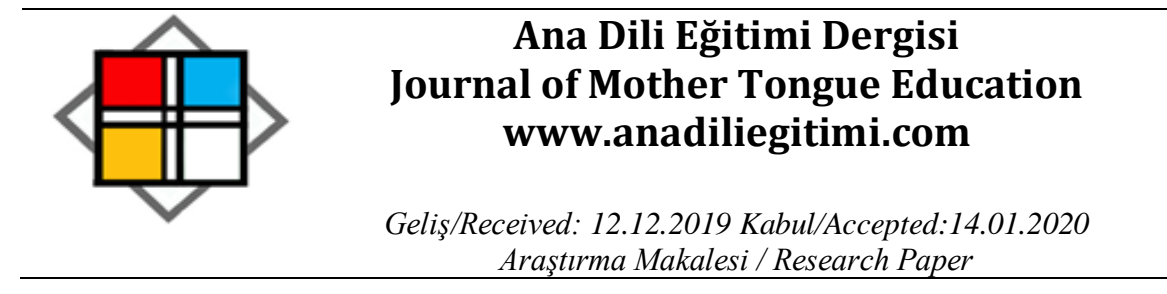

\title{
Düşünen Sınıf Materyallerinin (DSM) PISA Okuma Becerileri Üzerinde Etkisi
}

\author{
Sevda DOLAPÇIOĞLU*
}

\begin{abstract}
Öz
Üst düzey düşünme öğretimi tüm öğrenciler ve dersler için önemlidir. Düşünme becerilerinin gelişimini desteklemek için dili anlama sorunlarından biri, yazılı metinlerin anlaşılmaması üzerinedir. Bu çalışmanın iki ana amacı vardır. Bunlardan ilki DSM materyallerinin geliştirme ve uygulama özelliklerini sunmak. İkincisi ise bu materyallerinin PISA metin türlerini anlamaya etkisini araştırmaktır. Karma yöntem ile yürütülen çalışmada yarı deneysel araştırma deseni ve görüşme tekniğinden yararlanılmıştır. Çalışma grubu, 25 sekizinci sınıf öğrencisinden oluşmaktadır. Sonuç olarak DSM'nin sürekli ve süreksiz PISA metin türlerini anlamaya anlamlı etkisi olduğu bulunmuştur. Bu katkılar, cevaba dayanak sunma, paragraf sorularını okuma ve anlama, ana fikri anlama, sosyal destek, birbirini dinleme, Türkçe, Matematik ve Fen ve Teknolojileri ders başarısına olumlu katkıları tespit etme olarak sıralanabilir.
\end{abstract}

Anahtar Kelimeler: Düşünen sınıf materyalleri, PISA okuma becerileri, düşünme becerileri

\section{Effect of Materials for Thinking Classroom (MTC) on PISA Reading Literacy}

\section{Abstract}

Teaching of higher-order thinking skills is important in all subjects and for all students. One of the main problems of understanding language to support thinking skills is related to not comprehending written texts. This study had two main purposes. First of them was to explain how to develop and apply MTC. Second one was to investigate the effect of these materials on the comprehension of PISA text types. In the study conducted with Convergent Parallel Design, quasiexperimental research design and interview techniques were used. The study group consisted of 25 eight grade students. As a conclusion, it was found that MTC contributed to understanding continuous and discontinuous PISA text types. These contributions can be listed as evidenceproviding, reading and comprehension of paragraph questions, getting the gist, social support, peer listening, positive contributions to the success of Turkish, Math and Science lessons, attractive materials and encouraging to read.

Keywords: Materials for Thinking Classroom, PISA reading skills, thinking skills

\section{Giriş}

Öğretim programları temel beceriler yanında üst düzey becerilerin öğretimi üzerine yöneldiğinden bu yana düşünme becerileri üzerine tartışmalar alan yazında önemli hâle gelmiştir. Üst düzey düşünmenin tüm öğrenciler ve dersler için önemli olduğu ise yıllardır tartışılmaktadır (Doğanay ve Sarı, 2012; Hasan, 2019; Jerome, Cheng ve Hie, 2019; Karadüz, 2010; Miri, David ve Uri, 2007; Uysal, 2009; Zohar ve Dori, 2003). Bu beceriler okuduğunu anlama, eleştirel, yaratıcı düşünme, akıl yürütme, karar verme, iletişim ve problem çözme becerileri olarak sıralanabilir (Doğanay, 2017; Haladayna, 1997; Jerome, Cheng and Hie, 2019; Kusumastuti, Fauziati and Marmanto, 2019). Siralanan becerilerin tamamının istenilen düzeyde okul ortamında geliştirilebilmesi için yazılı metnin anlaşılması önemlidir. Yazılı bir metnin okunmasından sonra yorumlanması, farklı yorumların dinlenmesi, konunun üzerinde tartışııması, değerlendirmesi ve yeni anlamların keşfedilmesi gibi becerileri geliştirici sınıf içi

\footnotetext{
${ }^{*}$ Dr. Öğretim Üyesi, Mustafa Kemal Üniversitesi, Eğitim Fakültesi, Eğitim Bilimleri, HATAY, sdolapcioglu@mku.edu.tr, ORCID: 0000-0002-2707-1744
} 
uygulamalar tüm disiplinler için gereklidir ve dili anlama üzerinedir. Bu öğretim uygulamalarının sınıflarda geliştirilmesi için çözümler üzerine alan yazın tartışmaları iki boyuttadır. Bunlardan birincisi düşünen sınıflar için öğretmen desteğidir (Dolapçığlu, 2019; Newman, 1990; Doğanay ve Sarı, 2012; Şahin ve Sarı, 2016; Yüce, 2012). İkincisi düşünen sınıflar için öğrenme modelleri uygulamaları üzerinedir (Acosta ve Ferri, 2009; Fisher, 2001; Karadüz, 2010; Marzano, 2017; Newman ve Weglage,1993; Ramos, Dolipas; Villamor, 2013). Düşünen sınıflar için materyaller her iki tartışma alanının çözüm önerilerini destekler. Çünkü DSM, düşünen sınıf ortamı ve düşünen sınıf öğrenme modellerinin senteziyle üretilebilir.

Düşünen sınıf için öğretmen desteği öğretmen-öğrenci ilişkisi ve iletişime dayalı öğretmen davranışlarını içerir. Bu destek bilgi-duygu desteği ve yakınlık boyutunda öğretmenin öğrenci ile etkileşimine dayalı olabildiği gibi öğrenmenin düşünen sınıf bileşenlerini yansıtmasına da bağlıdır (Dolapçıŏlu, 2019). Bu bileşenler, sınıfta hatırlamanın ötesinde, anlamlı düşünmeyi sağlayıcı etkinlikler sağlama ve bu etkinliklere etkin katılım için öğrencileri teşvik etmek için çaba, sorulara yanıt için zaman tanıması, olarak sıralanabilir. Diğer taraftan öğrencileri dikkatli dinleme, düşüncelerini rahat ifade edebileceği huzurlu sınıf ortamı yaratma yönünde davranışlar düşünmenin öğrenildiği bir sınıftın düzeninde vardır (Doğanay ve Sarı, 2012; Udall ve Daniels, 1991). Düşünen sınıflar için öğretmenin sınıf içerisinde bir düşünme disiplinini yakalaması önemlidir. Bu rutinde öğrenilenlerin birkaç adımdan oluşması, basit bir şekilde tekrarı, hatırlanması ve kullanılması önemlidir. Diğer taraftan öğretmen düşünme için imkan oluşturmalı, etkileşimi desteklemeli ve düşünme ürünlerini sınıf ya da okulda sergilemelidir (Ritchhart, 2002). Fakat bir çok okulda düşünme becerilerinin öğretimine odaklanılanılmamaktadır. Bu yüzden temel problem düşünme öğretimi değil düşünmenin sınıftaki kendi eksikliğidir (Eraslan 2009; Newman,1990). Tartışılan bu sorunların giderilmesi için ders materyallerinin düşünen sınıf özelliklerini destekleyecek şekilde yapılandırılması ve kullanılması önemlidir. Bundan dolayı çalışmanın ana amacı, Türkçe dersi öğretimine yönelik düşünen sınıf ortamını destekleyen materyallerin özelliklerini sunmak ve bu materyallerin PISA okuma başarısına katkısını tartışmaktır.

PISA (Program for International Student Assessment), OECD üyesi ülkelerdeki 15 yaş grubu öğrencilerin okuma becerileri, fen okuryazarlığı ve matematik okuryazarlığı alanlarında başarılarını ölçen ve ülkelerin eğitim politikalarının gelişiminde temel alınan bir uygulamadır. Her üç yılda bir yapılan sınavın ana özelliği düşünme becerilerinin ölçülmesi üzerindedir. Ana dilini anlama ile ilgili öğretim uygulamalarının bugün okullarda düşünme becerilerini destekleme kaygısından uzaklaştığının en önemli göstergelerinden biri, PISA uluslararası okuma becerileri Türkiye başarısıdır (OECD, 2015). Matematik, fen bilimleri ve okuma alanında başarısızığın temelinde yazıı metinleri değerlendirme düzeyinde öğrenciler tarafından anlaşılmaması yatmaktadır (Donolatol, Giofrèl ve Mammarella, 2019; Durgun ve Önder, 2019). Üst düzey düşünme becerileri üzerine temellendirilmiş PISA okuma metinlerinin anlaşılması analiz, değerlendirme ve planlama gerektirir (Hasan, 2019; OECD, 2015; Venugopalan, 2019). Bilişsel süreçteki öğretim hedeflerinin son üç basamağı olan analiz, değerlendirme ve yaratma basamakları (Anderson and Krathwohl 2001) üst düzey düşünme becerilerini içine alır. Dinleme, konuşma, okuma ve yazma gibi temel dil becerilerinin gelişmesi düşünme becerilerinin gelişimine bağlıdır (Karadüz, 2010). Okullarda, okuma metinlerinin analiz, değerlendirme ve sentez boyutunda anlaşılması sadece Türkçe dersi değil Matematik, Fen ve Sosyal bilgiler alanı için de önemlidir. Yazılı bir metni anlama süreci bir çok etmenin etkileşimi sonrasında oluşur. Ayrıca, çıkarımda bulunma, ilişkileri belirleme, organize etme, kontrol gibi bilişsel süreçleri içerir (Doğanay, 2017). Bu becerilerin tamamı, eleştirel okuma sürecine işaret eder. Metinin anlamının okuyucunun zihninde oluşabilmesi için bağlamlaştırma, anlama için soru sorma, değer ve inanç üzerinde düşünme, anahtar sözcüklere dikkat etme, özetleme, değerlendirme, okuduğunu başka kaynaklarla karşılaştırma, hayal etme gibi eleştirel okuma stratejilerine intiyaç vardır (Doğanay, 2017, s.336-339). Eleştirel okuma üst düzey düşünme becerilerinden biridir ve bu beceri DSM'nin sınıf pratiklerinde doğru kullanımı ile gelişebilir. Çünkü düşünen sınıf öğrenme materyalleri öğrencinin bu becerileri kullanmasına yönelik aktiviteler içermektedir. Buradaki vurgu şu anda "yeni nesil soru 
tiplerinin" öğrencilere sadece çözdürülmesi üzerine odaklanan mevcut ders içi uygulamaların düşünen sınıfları destekleyen öğretim modelleri ile sentezlenmesi üzerine bilinç kazandırmak üzerinedir. Diğer taraftan, okullarda materyal çok uyaranlı öğrenme ortamı yaratma konusunda yeterli değildir (Göçer ve Akgül, 2019; Ichsan, , Sigit, ve Miarsyah, 2019). Türkçe ders kitabındaki metin sorularının çoğunluğu $(\% 66,8)$ basit anlama düzeyindedir (Sezgin ve Özilhan, 2019). Analiz, değerlendirme ve sentez sorularını içinde barındıran DSM'nin anlaşılması bu sorunların çözümüne katkı sağlayabilir.

PISA ana dili anlama başarı durumunu betimleyen değişkenlere ait ulusal pek çok araştırma vardır (Bozkurt, 2019; İşeri, 2016; Ören, Konuk, Sefer ve Sarıtaş, 2017, Tuzlukaya, 2019). Türkçe öğretim programı kazanımları ve ders kitablarındaki metinleri PISA başarısı açısından analiz eden yazarlar (Ören, 2017; Tuzlukaya, 2019), bu metinlerin daha üst düzeyde düşünme becerilerini geliştirecek şekilde yapılandırılmasına ihtiyaç olduğu sonucuna ulaşmışlardır. Diğer taraftan, metin türleri olarak yeni yaklaşımlara uygun olarak özel ve özgün türlerine kitaplarda yer verilmesine rağmen (Güneş, 2013) genel olarak Türkçe dersinde sınıf ortamını değerlendirmeye yönelik çalışmalarda anlama, anlatım aktivitelerine dayalı sosyal ortamın eksikliği olduğu (Karadüz, 2010) öğretmenlerin kullandıkları materyal ve tasarımların öğrenciye çok uyaranlı ortam oluşturma yönünde yetersiz kaldığı, daha çok hikâye, roman ve şiir metin türlerinin kullanıldığı (Göçer ve Akgül, 2019), metinler arası ve disiplinler arası bağ kurmanın öğretmenin bilgi-becerisine bırakıldığı, programda yeterli düzeyde açıklanmadığını (Karatay, 2010) ulusal alanda ana dilini anlama üzerine yapılan tartışmalardır. Alanda tartışılan boşluğu doldurmak için düşünen sınıf ortamını ve öğrenme modellerini içinde bulunduran materyallere ihtiyaç vardır. Çalışmanın amacı bu boşluğu doldurmaya yönelik bir katkı getirmeye yöneliktir. Öğrencilerin analiz ve değerlendirme düzeyinde yazılı metinleri inceleyebilmesi için düşünen sınıf özelliklerine uygun bir sınıf ortamını içinde barındıran DSM ile eğitim almalıdır. Bundan dolayı çalışma içerisinde DSM materyallerinin değerlendirme düzeyinde PISA metin türlerini anlamaya etkisi genel amacı doğrultusunda aşağıdaki sorulara cevap aranmıştır:

1) Düşünen sınıf materyallerine dayalı uygulamaların, yürütüldüğü sınıflarda deney grubu öğrencilerinin sürekli metni anlama puanlarına ilişkin ön ve son test puanları arasında anlamlı fark var mıdır?

2) Düşünen sınıf materyallerine dayalı uygulamaların yürütüldüğü sınıflarda deney grubu öğrencilerinin süreksiz metni anlama puanlarına ilişkin ön ve son test puanları arasında anlamlı fark var mıdır?

3) Düşünen sınıf materyallerine dayalı uygulamaların yürütüldüğg̈ sınıflarda deney grubu öğrencilerinin PISA okuma becerileri toplam puanlarına ilişkin ön ve son test puanları arasında anlamlı fark var mıdır?

4) Düşünen sınıf öğrenme modeli olarak düşünmeyi geliştirici materyal seçimi ve kullanımının süreklisüreksiz metinlerinin anlaşılmasına katkıları hangi boyutlardadır?

\section{Düşünen sınıflar için materyaller (DSM)}

Ana dilde anlama ve materyal geliştirme üzerine birçok araştırma makalesi olan Tomlinson, yazılı metinleri anlama üzerine materyal geliştirmenin sadece uygulayıcıların değil akademisyenler için de önemli bir konu olduğunu savunmaktadır. Bu süreç geliştiricilerin materyali değerlendirmesi, adaptasyonu, tasarımı, üretimi ve araştırılmasını içerir. İdeal olan bu süreçlerin eksiksiz tamamlanmasıdır (2012). Hangi öğrenme modelini seçersek seçelim materyallere ihtiyacımız vardır. Bu materyaller öğrenmeyi destekleyici (kitap, sözlük veya bilgisayar temelli kaynaklar) veya bilginin otantik içerik bağlantılı (film, diyalog ve roman) biçimde olabilir (Tomlinson, 2011). Ancak öğretmenlerin sınıf içi materyalleri seçerken ya da uygularken öğrencinin ihtiyacı ve öğretimsel hedeflere göre materyalin kullanılması hayati bir öneme sahiptir (Menggo, Suastra, , Budiarsa, ve Padmadewi, 2019). DSM, düşünen sınıf ortamı ve düşünen sınıf öğrenme modellerinin senteziyle üretilen gerçek yaşam içeriğiyle destekli materyallerdir. Bu materyallerin en önemli özelliği, düşünen sınıf ortamının oluşturulmasına yönelik öğrenci-öğretmen yönlendirme kılavuzu içermesidir. Kılavuz, öğrencileri dikkatli dinleme, düşüncelerini rahat ifade edebileceği huzurlu sınıf ortamı yaratma, hatırlamanın ötesinde anlamlı düşünmeyi sağlayıcı etkinlikler sağlama, etkileşimi destekleme (Ritchhart, 2002; Doğanay ve Sarı, 2012; Udall ve Daniels, 1991) konularında yönlendirici adımlardan 
oluşmaktadır. Diğer taraftan düşünen sınıfın öğrenme modellerine dayalı DSM uygulaması, ikili ya da dörtlü öğrenci grupları ile sınıf içi çalışma ortamı oluşturulmasına yönelik tasarlanmış öğrenme modellerini içermektedir. Bu amaçla DSM materyalleri, düşünen sınıf ortamını destekleyici analiz ve değerlendirme soruları etrafında tartışma etkinliklerini içermelidir. Acosta ve Ferri (2010)'e göre düşünme becerilerini geliştirici yazılı materyallerin iki temel özelliği biçimsel olarak taşıması önemlidir. Bunlardan biri, içerdiği soruların analiz ve değerlendirme düzeyinde olması ikinci olarak grafik şemalarını içermesidir. Buna karşın ulusal çalışmaları incelediğimizde öğrencilerin en çok kullandığı ders kitabı materyallerinin içerisinde yer alan metinlerin Barett taksonomisine göre daha çok basit anlama $(\% 66,8)$ düzeyinde olduğu belirlenmiştir. Yeniden organize etme $(\% 10,4)$, çıkarımsal anlama $(\% 8,8)$, değerlendirme $(\% 12,6)$ ve takdir $(\% 1,4)$ türünde sorulara da az oranlarda yer verildiği belirlenmiştir (Sezgin ve Özilhan, 2019). Ören ve ark. (2017), ortaokul Türkçe Öğretim Programlarındaki Metin Türleri ile PISA'daki metin türlerinin karşılaştırılması üzerine yaptıkları çalışma içerisinde PISA metin türlerinden çoklu ve karışık metinler, yönergeler, belge ve kayıtlar, hipermetinler (hypertext), faaliyet metinleri (transaction)'nin Türkçe öğretim programlarında yer almadığı sonucuna ulaşmıştır. Sadece öyküleyici, betimleyici, bilgilendirici ve tartışmacı metinlerin programda yer aldığı ancak bu metinlerin de günlük hayata daha az dönük ve daha az detaylı olduğu sonucuna ulaşmıştır. Oysa DSM temel özelliklerinden biri de içeriğin öğrenen tecrübesine dayalı gerçek hayat konularını içermesidir (Newman ve Weagle, 1993). Tuzlukaya (2019) benzer şekilde, bu bağlamda Türkçe Dersi (1-8. Sınıflar) Öğretim Programı́ndaki okuma alanı ile ilgili kazanımlarla PISA yeterlilikleri karşılaştırılı̆̆ında Türkçe dersi kazanımlarının daha çok alt düzey becerileri gerçekleştirmeye yönelik olduğu sonucu ortaya çıkmaktadır. İşeri (2019), ise ortaöğretim, dokuzuncu sınıf Fen bilimleri, Matematik ve Edebiyat dersleri öğretim programları kazanımlarının, ilk aşamada bilgi türü ve bilişsel nitelikler açısından içerik analizleri ve söylem okumaları içerdiğini bulgusunu sunmuştur. Bozkurt (2016), PISA okuma ölçeğinde 2. düzey ve altında kalan Türk öğrencilerin çoğunluğunun üst düzey bilişsel işlemleri gerektiren sorularda daha düşük doğru yanıtlama ortalaması elde ettiği bulgusuna ulaşmıştır. Bu bakımdan ülke eğitim materyallerini tekrar gözden geçirerek, üst düzey bilişsel taksonomiye uygun soruları ve düşünen sınıf ortamını içerecek şekilde yapılandırılmalıdır. DSM materyallerinin taşıması gereken özellikler, düşünen sınıf ortamı ve düşünmeyi destekleyen öğrenme modelleri araştırmaları temel alınarak şu şekilde özetlenmiştir:

1) Gerçek Dünya Bağlamı: Doğrudan gerçek dünya ile bağlantı kurma metin bilgisi ile iletişim kurmayı sağlamaktadır. Öğrenciler sunulan okuma metinini hem anlamalı hem de içerikte yer alan bilgi ile iletişim kurabilmelidir. Okunan metin ile iletişim şu durumlarda kurulabilir (Newman ve Weagle, 1993):

Öğrenci gerçek dünya problemleri üzerinde düşünürken,

Bilgiyi uygulamak için içerik olarak kendi tecrübelerini kullanırken,

2) Analiz: Üst düzey düşünmeye dayalı materyallerin çıkarım yapma, görselleştirme ve tahmin etme bileşenlerine dayalı olması gereklidir (Furst,2019). Öğrenciler, anlam çıkarmak metin içi birkaç bilgi arasında bağ kurabilmelidir. Kurulan bağlam üzerinde ikili ve dörtlü sınıf içi tartışmalar, metin içerisinde yer alan kelimelerin yerine aynı manayı taşıyan farklı kelimeler bulma, (Marzano, 2017; Newman,1990) çalışmaları ile metin analiz edilmelidir. Metnin bilinmeyen kelimelerinin sadece sözlükteki karşılığı üzerindeki tanımlar anlama için yeterli bir çalışma değildir hatta çoğu zaman sözlükteki anlam, metin bağlamıyla uyumlu değildir (Sammons, 2011). Bu sebeple tanımın yanında analiz ve değerlendirme çalışmalarına yönelik düşünen sınıflar oluşturmak için yönelim olmalıdır.

3) Düşünen Sınıf Ortamı ve Katılım: Sunulan bilgiden bir hipotez çıkarmak için okuma metininden anladıklarını akranları ile iletişim kurarak birbirine anlatmalı. Bunu sağlamanın yollarından biri de ikili ya da dörtlü sınıf içi grup tartışma teknikleridir. Bu sebeple iletişime dayalı, öğrencilerin birbirine ve öğretmenle fikirlerini paylaşabileceği, sınıf ortamlarının oluşturulması önemlidir(Ritchhart, 2002; Udall ve Daniels, 1991). DSM temel özelliği bu tür sınıf ortamı yaratma üzerindedir. Anlamlı diyaloğun çok az olduğu, ya da hiç olmadığı sınıflarda eğitim öğretmenin plana bağlı kaldığı ve öğrencilerin kısa cevaplar verdiği bir etkileşim ortamı vardır (Newman ve 
Weagle, 1993). Kısa süreli etkileşim ve öğrencilerin gruplar hâline çalışmadığı sınıf ortamları DSM için uygun değildir. Çünkü öğrenciler tartışırken düşünme becerilerini geliştirirler ve dikkatlerini toplarlar (Newman,1990). ). Diğer taraftan sosyal öğrenme ortamı ve işbirlikli grup çalışmaları, daha derin düşünmeyi destekleyerek anlama, eleştirel düşünme ve bilişsel farkındalık gibi düşünme becerilerini geliştirmektedir (Fisher, 2001).

4) Değerlendirme: Materyal değerlendirme düzeyinde sorular içermelidir. Düşünme becerilerinin gelişimi için materyalin cevabı kişiden kişiye değişebilen yorumlara izin verecek değerlendirme düzeyi sorular içermesi gereklidir. Tomlison ve Masuhara (2004), materyal içerisinde yer alan soruları değerlendirirken; her bir soru cevaplanabilir mi?, Doğmatik bilgiden sıyrılmış mı?, Her bir soru diğer değerlendiricilerin de aynı şekilde anlayabileceği kadar güvenilir mi? gibi incelenmesi gerektiğini vurgulamışlardır. Düşünme becerilerini geliştirici yazılı materyallerin iki temel özelliğinden biri, içerdiği soruların analiz ve değerlendirme düzeyinde olmasıdır (Acosta ve Ferri, 2010).

5) Zaman: Okudukları ile ilgili hislerini ve düşüncelerini anlatacağı yeterli zamanı vermesi gerekir (Udall ve Daniels, 1991). Buradaki vurgu, bilginin derinliği üzerinedir. Bilgi, bir ders ya da konunun ana fikri üzerinde durduğu zaman derindir. Öğrenciler için bilgi, net ayrımlar yapabildiği, tartışma geliştirebildiği, problem çözdüğg̈ ve açıklamalar oluşturduğunda derindir (Newman ve Weagle, 1993).

6) Sürekli ve süreksiz metinler: Sürekli metinler genellikle bir paragraf olacak metinlerden oluşurken, süreksiz metinler daha çok bir matris formatında, listeler, tablolar, grafik ve şekillerden oluşmaktadır (MEB, 2012 ). Düşünen sınıf materyalleri, her iki metin şeklini de içerebilir. Düşünme becerilerini geliştirici yazılı materyallerin iki temel özelliğinden biri, grafik ve şemaları içermesidir (Acosta ve Ferri, 2010).

Sonuç olarak DSM materyallerinin işbirliği ve iletişime dayalı düşünen sınıf ortamı özelliklerini, düşünme becerilerini geliştiren açık uçlu soru tiplerini de içerdiğini ve gerçek yaşam bağlamı içerikli metin türlerine dayalı olduğunu söyleyebiliriz. Diğer taraftan DSM, düşünme becerilerini destekleyici öğrenme modellerine dayalı aktiviteler ve düşünen sınıflar için yapılandırılmış uygulama sürecini içermelidir. Düşünen sınıf ortamı yaratma özelliği, DSM materyallerinin en önemli özelliğidir. Aksi hâlde materyaller düşünme becerilerinin gelişimi için eksik kalabilir. Bu durumda çeşitli disiplinler arası materyal geliştirme gruplarının oluşturulması, değerlendirme rubriklerinin hazırlanması ile materyal geliştirmenin yapılandırılması gereklidir (Steer, Iverson, Egger, Kastens, Manduca ve McConnell, 2019).

Materyallerin düşünme becerilerini destekleyecek öğretim tasarımlarını içerecek şekilde sınıf içinde öğretmenler tarafından kullanımı önemlidir. Öğrencilerin rutin olmayan problemlerle ilgili bilgilendirilmesi ve bu bilgiyi analiz edebilecekleri, yorumlayabilecekleri, değerlendirme yapabilecekleri ve kullanabilecekleri aktivitelere dönüştüren ve düşünen sınıf ortamında uygulanan materyaller düşünme becerilerini geliştirebilir. Düşünme becerilerini geliştirici materyallerin materyal geliştirme takımları ve işbirliği yoluyla geliştirilmesi ve düşünme becerilerini destekleyip desteklemediğinin değerlendirilmesi bu süreçte önemlidir.

\section{Araştırmanın Modeli}

\section{Yöntem}

Çalışmanın odak noktası DSM kullanılarak oluşturulan öğrenme ortamının sürekli-süreksiz metin türlerini anlamaya etkisi ve bu etkinin en çok hangi boyutlarda olduğu üzerinedir. Bu sebeple araştırmada yakınsayan paralel karma yöntem kullanılmıştır. Hem nicel hem de nitel verilerin tek bir çalışma içinde toplanması ve analiz edilmesine odaklanan karma yöntemin kullanılması, olgunun en iyi biçimde anlaşılmasına katkı sağlamaktadır (Creswell, 2003; Onwuegbuzie ve Leech, 2004). Yakınsayan paralel karma yöntem deseni kullanılan bu araştırmanın nicel boyutu deneysel araştırma modellerinden ön tek gruplu ön test son test desenine göre tasarlanmıştır. Nitel boyutunda ise görüşme tekniğinden yararlanılmıştır. Nicel veriler sınıf ana dili başarı ortalamasının yorumlanmasında, nitel veriler ise bu başarının hangi boyutlarda olduğunun belirlenmesi amacıyla kullanıımıştır. Çalışmanın süresi haftada 4 saat olmak üzere toplam 20 ders saatidir. Türkçe dersleri araştırmacı tarafından DSM materyalleri temel alınarak yürütülmüştür. 


\section{Örneklem / Araştırma grubu}

Araştırmanın çalışma grubunu Hatay ili Antakya ilçesindeki bir devlet ilköğretim okulunun 8. sınıfında bulunan 25 öğrenci oluşturmaktadır. Çalışmaya katılan öğrencilerin $11^{\prime}$ i erkek, 14'ü kızdır. Görüşmeye amaçlı örnekleme türlerinden ölçüt örnekleme türü ile seçilen 16 öğrenci katılmıştır. Ölçüt olarak gönüllü katııım ve son test başarı puanları temel alınmıştır.

\section{Veri Toplama Araçları}

Başarı testi ve Puanlama cetveli (Puanlama Anahtarı) : Düşünme becerilerin ölçülmesi için geliştirilen testlerin açık uçlu yanıtlarının olması ve dereceli puanlama anahtarı ile değerlendirilmesi önemlidir. PISA sınavı odak noktası düşünme becerilerinin gelişimini belirlemeye yöneliktir. Bu amaçla başarı testi, 2015 yılı PISA sınavında kullanılan ve MEB (2015) tarafından Türkçeye uyarlanan örnek okuma becerileri sorularından uzman görüşü alınarak seçilmiştir. Metinlerin bilgi alanı öyküleme, yorumlama ve tartışmaya yönelik düz yazıları içeren sürekli metinler ve grafik, form ve listelerden oluşan süreksiz metin olmak üzere iki ayrı yapıdadır. Bu metinlerin tamamı ve içerdiği sorular bir Türkçe alan eğitimcisi ve 3 öğretim programı alanında çalışan uzmanlar tarafından incelenmiş ve toplam 3 metin ve 13 adet sorunun veri toplama aracı olarak kullanılmasına karar verilmiştir. Dereceli puanlama anahtarının güvenilirliğini test etmek için çalışma öncesi 10 öğrenci ile pilot çalışma yapılmıştır. íki kişinin yanıtlara vermiş olduğu puanlar üzerinden uyum indeksi (güvenirlik düzeyi) Cohen's Kappa formülü ile incelenmiş ve uyum düzeyi .82 olarak belirlenmiştir. Dereceli Puanlama anahtarı her açık uçlu soru için tam puan, kısmi puan ve 0 puan olmak üzere üç farklı düzey içerir. Öğrencilerin puanlama anahtarından alabileceği en düşük puan, 0 ; en yüksek puan ise, metin öyküleri yorumlama, tartışma gibi düz yazıları içeren sürekli metinleri okuma becerisi için 18; grafik, form ve listeleri içeren süreksiz metin okuma becerisi için 8 ve toplam test için $26^{\prime}$ dır.

\section{Görüşme Soruları}

Görüşme formunda PISA örnek sorularının gözden geçirilmesi ve yapılan alan yazın taramasından yola çıkılarak araştırmanın konusu bağlamında "düşünen sınıf ana dili anlama materyallerinin ve öğrencinin metin ötesinde bir fikir sunma, ana fikri bulma, paragraf sorularını okuma ve anlama, görüşünü dayanakları ile sunma boyutunda öğrenciye katkıları, sorunlar ve öneriler" şeklinde düzenlenen kategorilere ilişkin sorular yer almıştır. Görüşme öncesinde iki yedinci sınıf öğrenci ile pilot görüşme yapılmıştır ve görüşme soruları anlaşılırlık açısından değerlendirilmiştir.

\section{Çalışma içerisinde kullanılan materyaller}

Materyaller metin, açık uçlu sorular ve öğretim süreci uygulama adımları için kılavuz olmak üzere üç bölümden oluşmaktadır. Metinler, yorumlama ve tartışma içeren sürekli metinler ve grafik, form ve listeleme içeren süreksiz metinler olmak üzere iki yapıdadır. Materyal içerisindeki sorularının odaklandığı temel beceri ve düşünme süreçleri, bilgiye ulaşma ve bilgiyi hatırlama, bilgiyi bir araya getirme ve yorumlama, kendi düşüncelerini yansıtma ve metni değerlendirme olmak üzere 6 taksonomik düzeyi içermektedir (PiSA, 2015). Öğretim süreci kılavuzu, düşünen sınıf öğretmen ve öğrenci davranışlarına yönelik hatırlatmalar, materyalin kullanımı sırasında öğrencilerin yapacağı çalışmalar, öğretim yöntem ve tekniklerinin adımları bilgilerini içermektedir. Materyaller geliştirilirken öğretim programı kazanımları, ders kitabı metinleri, PISA örnek soruları, düşünme becerilerini destekleyici öğrenme ilkeleri (Newman ve Weagle, 1993; Marzano, 2017), düşünme dostu öğretmenöğrenci davranışları (Doğanay ve Sarı, 2012; Udall ve Daniels, 1991; Ritchhart, 2002), öğretim sürecinde düşünmeyi geliştirici üst düzey soruların değerlendirilmesi (Haladayna, 1997; Kutlu, Doğan, Karakaya, 2010) düşünmeyi geliştiren materyal özellikleri (Acosta ve Ferri, 2010; Tomlison ve Masuhara, 2004) alanında yapılan çalışmalardan yararlanıımıştır. 


\section{Verilerin toplanması ve Analizi}

Araştırma içerisinde iki türlü veri toplanmıştır. Illk veri, DSM’ nın okuma becerileri gelişime yansımasına yönelik değerlendirme için başarı testi puanlama anahtarından elde edilen nicel bulgudur. Diğeri ise öğrenci görüşmelerinden elde edilen nitel bulgulardır. Analizler ise alt problemler temel alınarak çözümlenmiştir. Birinci alt problemde, ön ve son test başarı ortalamaları arasındaki farkın anlamlı olup olmadığını araştırmak için p (olasılık) değerine bakılmıştır. İkinci alt problemde, bu farkın hangi düşünme becerileri ve dolayısıyla ana dili anlama boyutlarında olduğunu incelemek için öğrenci görüşleri kayıt altına alınmıştır. Ardından tam metin hâline getirilen kayıtlar içerik analizi ile incelenmiş, ilgili tema ve kodlar sunulmuştur. Ardından aynı metinler öğretim programları alanında bilimsel çalışmaları olan farklı bir uzman tarafından da gözden geçirilmiştir. İki kodlayıcı güvenirliği Miles ve Huberman'ın (1994) önerdiği; "P(Uzlaşma Yüzdesi\%)=[Na(Görüş Birliği)/ Na(Görüş Birliği)+Nd (Görüş Ayrılığı)]X100" güvenirlik formülüyle hesaplanmış ve \%91 sonucuna ulaşılmıştır. Nicel puanlama için öğrenci ön ve son test yanıtları dereceleme puanlama anahtarı kullanılarak iki araştırmacı tarafından değerlendirilmiş, puanlar arasındaki uyum için yapılan istatistik sonucunda korelasyon katsayısı ön test için.81; son test için .86 olarak bulunmuştur.

\section{Bulgular}

Araştırmada elde edilen verilerin analizi sonucunda, sürekli metin ve süreksiz metin okuduğunu anlama ilgili bulgular aşağıda sunulmuştur. Düşünme becerilerini geliştiren materyaller kullanılarak yürütülen çalışmanın sekizinci sınıf öğrencilerinin sürekli metin okuduğunu anlama başarısı ön ve son test puanları arasında fark var mıdır? Sorusuna yönelik bulgular tablo 1'de sunulmuştur.

Tablo 1.

Sürekli metin okuma becerileri ön-son test puanlarına ilişkin eşli gruplar t testi analiz sonuçları

\begin{tabular}{lcccccc}
\hline Deney Grubu & $\mathrm{n}$ & ort. & SS & sd & $\mathrm{t}$ & $\mathrm{p}$ \\
\hline Ön test & 25 & 8 & 3 & & & \\
Son test & 25 & 11.13 & 2.9 & & & \\
\end{tabular}

$* p<.01$

Tablo 1'de görüldüğü gibi çalışma grubundaki öğrencilerin sürekli metin okuma becerileri ön test puanlarının ortalamaları 8 iken; son test puanlarının ortalamaları 11.13'e yükselmiştir. Bu iki ortalama arasında anlamlı bir fark olup olmadığını belirlemek için yapılan eşli gruplar t testi sonucunda farkın anlamlı olduğu bulunmuştur $[t(24)=-5.14, p=.000]$. Bu bulgu DSM' nin sürekli metinleri okuma becerisini geliştirdiğini ve iki değişken arasında anlamlı bir ilişkinin olduğu şeklinde yorumlanabilir.

DSM çalışmalarının sürekli metin anlamaya katkısının hangi boyutlarda olduğuna yönelik öğrenci görüşlerini analiz ettiğimizde en büyük katkının akademik ders başarısının artması ( $n=16)$ ve paragraf sorularını anlama $(n=12)$ boyutunda olduğunu görmekteyiz. Diğer taraftan metin içinde ana fikri bulma $(n=10)$, metin içinde yer alan ana ve yan cümleleri keşfetme $(n=7)$ boyutlarında gelişimler olduğu bulgusuna da ulaşılmıştır. Konu ile ilgili öğrenci alıntıları şu şekildedir:

Geçen bir derste öğretmen senin paragraf sorusunu çözme ile ilgili sorunların çok azaldı, iyi yapmaya başladınız dedi. Daha önce Türkçe derslerinde metin okurken bir kelimenin yerine hangi kelimeler gelebilir diye hiç düşünmezdim. Artık farklı kelimeler kullanabiliyorum bu da doğrudan paragraf sorularını anlamamı sağlıyor (K10).

Eskiden paragraf sorularında ana fikri her zaman bulamıyordum ve bu konuyla ilgili soruları kaçırdığımdan ilk sınavdan 80 almıştım. Bu metinler üzerinde çalıştıktan sonra ikinci sınavda 100 aldım. Örneğin eskiden bir paragrafı anlamak için birkaç defa okumak zorunda kalıyordum 
fakat şimdi bir kez okuduğumda anlayabiliyorum ve anlamdan birden fazla sonuç çıkarabiliyorum(K16).

Yorum sorularında genel olarak metin içinden direkt alıyordum ve hemen diğer soruya geçiyordum. Artık farklı kelimelerle ve kendi cümlelerimle ifade edebiliyorum. Ayrıca daha uzun yazabiliyorum. Paragraf sorularını daha çabuk anlamaya başladım (K12).

Türkçe yazılııından 100 aldım. Yorum gücüm gelişti. Eskiden paragrafı beş kez okusam da anlamıyordum şu an bir kere okuyup anlıyorum. Paragrafla sorularını rahatıkla çözebiliyorum (K3).

DSM kullanılarak yürütülen çalışmanın sekizinci sınıf öğrencilerinin süreksiz metin okuduğunu anlama başarısı ön ve son test puanları arasında fark var mıdır? Sorusuna yönelik bulgular tablo 2'de sunulmuştur.

Tablo 2.

Süreksiz metin okuma becerileri ön-son test puanlarına ilişkin eşli gruplar t testi analiz sonuçları

\begin{tabular}{lcccccc}
\hline & $\mathrm{n}$ & ort. & SS & sd & $\mathrm{t}$ & $\mathrm{p}$ \\
\hline Ön test & 25 & 1.79 & 1.62 & & 3.45 & .002 \\
Son test & 25 & 2.96 & 2.07 & & & \\
\hline
\end{tabular}

${ }^{*} p<.01$

Tablo 2'de görüldüğü gibi çalışma grubundaki öğrencilerin süreksiz metin okuma becerileri ön test puanlarının ortalamaları 1.79 iken; son test puanlarının ortalamaları 2.96'ya yükselmiştir. Bu iki ortalama arasında anlamlı bir fark olup olmadığını belirlemek için yapılan eşli gruplar $t$ testi sonucunda farkın anlamlı olduğu bulunmuştur [t(24)=-3.45, $p=.002]$. Bu bulgu düşünen sınıf materyallerinin süreksiz metinleri okuma becerisi geliştirdiği ve iki değişken arasında anlamlı bir ilişkinin olduğu şeklinde yorumlanabilir.

DSM materyalleri arasında matris formatında, grafik ve tablolardan oluşan metinleri de içerdiğinden konu ile ilgili bazı boyutlarda gelişimler olmuştur. Öğrenci görüşlerini analiz ettiğimizde öğrencilerin diğer derslere yönelik grafik, işaret ve konu bağlantısı kurduklarını ve bu bağlantının ders başarııını arttırdığını ifade ettikleri görülmektedir. Yarıya yakınında fen ve teknoloji $(n=7)$ ve matematik $(n=6)$ derslerini anlama becerilerin geliştiğini ifade etmiştir. Konu ile ilgili öğrenci alıntıları şu şekildedir: (K11).

Tanklar ve hız ile ilgili metini incelerken, Fen ve Teknoloji dersi yer alan hız konusunu anladım

Görselleri, sembolleri okuma becerim geliști. Ilk zamanlar görsel metnin ne anlatmaya çalıştığını fark edemiyordum. Sadece üzerindeki yazılara odaklanıyordum. Şimdi üzerinde yer alan sembollerin de ne anlama geldiğini anlamaya başladım (K10).

Grafik okuma çalışmaları sayesinde matematik dersindeki grafikleri okuma becerimi geliştirdi. Artık, Matematik sorularında ana fikri anlayabiliyorum. Istenilen bilgiyi bu bilgiden yararlanarak bulabiliyorum (K16).

Düşünme becerilerini geliştiren materyaller kullanılarak yürütülen çalışmanın sekizinci sınıf öğrencilerinin PISA okuryazarlık başarısı ön ve son test puanları arasında fark var mıdır? Sorusuna yönelik Bulgular tablo 3'de sunulmuştur. 
Tablo 3.

PISA okuma becerileri Ön-Son test Puanlarına iliş̧kin eşli gruplar t testi Analiz Sonuçları

\begin{tabular}{lcccccc}
\hline & $\mathrm{n}$ & ort. & SS & sd & $\mathrm{t}$ & $\mathrm{p}$ \\
\hline Ön test & 25 & 9.7 & 4.04 & & & \\
Son test & 25 & 14.08 & 3.94 & & 5.97 & .000 \\
& & & & & & \\
\hline
\end{tabular}

$* p<.01$

Tablo 3'de görüldüğü gibi çalışma grubundaki öğrencilerin PISA okuma başarısı ön test puanlarının ortalamaları 9.7 iken; son test puanlarının ortalamaları 14.08'e yükselmiştir. Bu iki ortalama arasında anlamlı bir fark olup olmadığını belirlemek için yapılan eşli gruplar $t$ testi sonucunda farkın anlamlı olduğu bulunmuştur [t(24)=-5.97, $p=.000]$. Bu bulgu, düşünen sınıf materyallerinin PISA okuma becerileri gelişimini arttırdığı ve iki değişken arasında anlamlı bir ilişkinin olduğu şeklinde yorumlanabilir.

DSM ‘nin gerçek hayat içerik bağlantısı ilkesinin öğrencilerin materyallere yönelik ilgisini çektiği $(n=12)$ şu şekilde ifade edilmiştir:

Eskiden derslerde bir kişiyi dinlediğimde sıkılırdım. Şimdi anlayabiliyorum, hatta farklı düşünceler sunabiliyorum. Gerçek hayattan alınan metinle bu bakımdan benim anlamamı geliştirdi. Diğer metinler gerçekte yaşamımızda olmayan konular ve çok ilgimi çekiyor. Ama sizin kullandığınız metinler gerçek hayatta var ve çok ilgimi çekiyor (K16).

Gruplar hâline çalışıyoruz, birbirimizi dinliyoruz ve farklı fikirler sunduğumuzda birbirimizin düşüncelerini kanıt sunarak çürütebiliyoruz. Bunu destekleyen metinler çok ilgimi çekti. Özellikle hayvanların hızı ile ilgili bir sürü şey öğrendim... robot Sofianın vatandaşlık alması konusu da çok güzeldi. (K3).

Gerçek hayatta yer alan konuları kullanmanız çok dikkatimi çekti. Gerçek hayatta yaşanan olayları metne yansıtınca (asker tankları, fil ve kaplumbağa hızı, robot sofia, Arsuz'da yaşanan yangın) okumayı sevmeye başladım. Arkadaşlarımın fikirlerine daha çok önem vermeye başladım. Bir soruyu çözerken bir sürü fikir yakalayabiliyorum. Arkadaşlarıma bu fikirleri iletme ve soru sorma fırsatı yakaladım. Sınıfta işbirliğimiz arttı (K10).

Konu ile ilgili nitel bilgileri analiz ettiğimizde elde edilen en önemli bulgulardan biri DSM kullanımının yarattığı düşünen sınıf ortamı ile ilgilidir. Bu materyallerin en önemli farkı düşünen sınıf özellikleri ilkelerini içermesidir. Düşünen sınıf ortamı için, öğrencilerin cevabını bir kanıta dayandırma (n: 8), birbirini dinleme (n:10), sosyal sınıf içi destek (n:16) boyutunda katkılarının olduğu görülmüştür: Başta Türkçe ve Matematik dersleri olmak üzere diğer derslerimde de anlama ve dinleme becerim gelişti. Eskiden grup çalışması, arkadaşlarıma soru sorma, birini dinleme ve fikir ifade etme gibi etkinlikler yapmıyorduk. Ama bu derste hepimiz gruplar hâline paragrafları tartıştık (K7).

Paragraf sorularında ben çok kötüydüm. Ama sizinle çalıştıktan sonra paragrafları yorumlamaya ve ana fikri bulmaya başladım. Ayrıca sınıfa yeni geldiğim için eskiden beni küçümsüyorlardı şimdi siz birbirinizi desteklemeye önem verin dediğiniz için bana da artık soru soruyorlar. Türkçe dersleri böyle olmalı (K5).

Bir metni okuduğumuzda eskiden hepimiz bir kişiyi dinler ve onun söylediklerini tekrar ederdik. Ancak şimdi farklı düşünebiliyor ve nedenlerini açıklayarak birbirimizi ikna edebiliyoruz. Örneğin Yusuf'u çok inatçı ve kendi fikirlerini körü körüne savunduğu için başlarda ikna edemiyorduk. Ama şimdi onu cevabın nedenlerini açıklayarak ikna edebiliyoruz (K6).

Metin sorularında cevabın her zaman net olmaması bizi düşündürdü. Artık farklı yorumlar yapabiliyoruz. Dinleme becerimiz gelişti ve sizin yaptığınız çalışmalarla arkadaşlarımızla daha 
iyi iletişim kurmaya başladık. Birbirimizden farklı yanıtlar verdiğimizde nedenlerini açıklayarak ikna ettik (K8).

\section{Tartışma, Sonuç ve Öneriler}

Sürekli metinleri anlama açısından DSM, öğrenci başarısını anlamlı düzeyde etkilemiştir. Bu başarının hangi boyutlarda olduğuna yönelik nitel bulgular detaylı incelendiğinde öğrencinin akademik ders başarısını olumlu etkilediği, metin içinde ana fikri bulma, metin içinde yer alan ana ve yan cümleleri keşfetme, paragraf sorularını okuma ve anlama becerilerini geliştirdiği bulgusuna ulaşılmıştır. DSM materyalleri düşünen sınıf yaratmak için analiz ve değerlendirme soruları içermekte ve öğrencinin etkin katılımına yönelik stratejiler içerdiğinden başarıyı etkilemiş olabilir. Tavşancıgil, Yıldırım ve Demir (2019) öğrenmeye yönelik üst düzey stratejileri daha sıklıkla kullanan öğrencilerin, okumaktan daha çok zevk aldığını bulgusuna ulaşmıştır. Üst düzey düşünmeye dayalı materyallerin çıkarım yapma, görselleştirme ve tahmin etme bileşenlerine dayalı olması gerektiğini ifade eden Furst (2019) bu materyallerin okuduğunu anlama üzerine olumlu etkisi olduğu bulgusuna ulaşmıştır. Türkçe öğretiminde öğrencilerin metni anlamaları, öğrenme sürecine aktif olarak katılmaları, metni çözümlemeleri, eleştirel düşünme becerilerini aktif olarak kullanabilmeleri ile mümkün olacaktır (Tuzlukaya, 2019). Koç'un (2011) bir ilköğretim okulunun iki sekizinci sınıfında yürüttüğü deneysel çalışmada, aktif öğrenmenin öğrencilerin okuduğunu anlama başarıları ve eleştirel düşünme becerileri üzerinde geleneksel öğretim yöntemlerine göre daha etkili olduğu saptanmıştır. Uysal (2009) Türkçe dersinde işbirlikli çalışma ortamının öğrencilerin eleştirel düşünme alt boyutları üzerinde anlamlı fark yarattığı sonucuna ulaşmıştır. Bu alt boyutlar: analiz, yorumlama, çıkarım yapma, değerlendirme, açıklama yapmadır. Türkçe öğretiminde eleştirel düşünme becerilerini kazandırma, dil becerilerinin desteklenip geliştirilmesi bakımından oldukça önemlidir. Dinleme, konuşma, okuma ve yazma gibi temel dil becerilerine ait kazanımların gerçekleştirilebilmesi için öğrencilerin eleştirel düşünme becerilerini geliştirmek gerekir. Eleştirel okuma, eleştirel dinleme, eleştirel konuşma ve eleştirel yazma ile ilgili kazanımların varlığı eleştirel düşünmeye bağlıdır (Karadüz, 2010). Bu çalışma içerisinde de benzer şekilde öğrenenlerde DSM'nin cevabı bir kanıta dayandırma becerisini geliştirdiği bulgusuna ulaşılmıştır. PISA sınav başarısında üst düzey düşünme içeren değerlendirme ve analiz basamaklarını içeren eleştirel düşünme becerisi için kanıt ve dayanak sunma önemli bir gelişimdir. Nitekim eleştirel düşünme gelişimi olan sınıflarda okuduğunu anlama daha yüksek düzeyde olmaktadır (Thamrin ve Agustin, 2019). Eleştirel düşünme okuduğunu anlama ile başlar ve temel düşünme becerilerinden biridir. Bu nedenle anlama ve ifade etme becerisi için, ana sınıfından ortaöğretime kadar programlar materyal ile desteklemeli ve öğrenenlere sunulmalıdır (Huizinga, Handelzalts, Nieveen ve Voogt, 2014).

Düşünen sınıf materyallerinin mevcut sınıf ortamında kullanılan materyallerden en önemli farkı düşünen sınıf ortamı destekli öğretmen öğrenci davranışlarını içermesidir. Bu yapı, deney grubunun öğrencilerin sosyal sınıf içi destek ve öğrencilerin birbirinin cevabını dinleme imkânı sunarak anlamayı geliştirmiştir. Destek, öğretmenin öğrencilerin neyi anlamadığını bilmesi, problemi çözmek için öğrencilere şans tanıması, öğrencilerin karşılaştıkları zorlukların üzerinden gelmesine yardımcı olması anlamına gelir. Fakat öğretmen desteği yeterli olmazsa öğrenci analiz ve değerlendirme gibi üst düzey düşünme becerilerini kullanamaz (Hasan, 2019). Diğer taraftan Schröter ve Kochva (2019), okuma okur-yazarlığının gelişimi üzerinde yaptıkları çalışmada sosyal etkileşime dayalı çalışmanın bilişsel gelişimi destekleyen temel faktör olduğu bulgusuna ulaşmıştır. Lei, Wen, Li, Kong, Chen ve Li (2019) ise yaptığı çalışmada, üst düzey düşünme becerilerini geliştirici stratejiler yoluyla öğretmen desteğinin okuduğunu anlamayı geliştirdiği bulgusuna ulaşmıştır. Bu araştırmada sürecin başında öğrenciler metinleri anlayamıyor ve katılım istemezken sürecin sonuna doğru daha iyi anladıklarını, arkadaşlarını dinleme, cevabı paylaşma ve karşılaştırma ortamının okuduğunu anlamalarını geliştirdiği sonucuna ulaşılmıştır. Bu ortam doğrudan düşünme dostu sınıfları işaret etmektedir (Doğanay ve Sarı, 2012; Newman ve Weglage,1993). İşbirliğine izin veren materyallerin anlam çıkrama, analiz ve değerlendirme yapmada daha etkili bulunmaktadır (Kucan ve Beck, 1997). Diğer taraftan sosyal 
öğrenme ortamı ve işbirlikli grup çalışmaları daha derin düşünmeyi destekleyerek anlama, eleştirel düşünme ve bilişsel farkındalık gibi düşünme becerilerini geliştirmektedir (Fisher, 2001). Öğretim programlarının felsefesinin sosyal ortamı destekleyici yapılanmasına rağmen sahada Türkçe öğretim ortamlarının hâla davranışçı anlayış etkisinde olduğunu doğrulayan çalışmalar vardır (Karadüz, 2010). Tüm bu sebeplerden dolayı öğrencilerin okuduğunu anlama ve anlatma yeterliliklerinin arttırılması konusunda düşünen sınıf ortamı ve modellerinin kullanımı konusunda öğretmenler bilinçlendirilmesi önerilebilir.

Çalışma içerisinde elde edilen diğer bir bulgu, düşünen sınıf materyallerinin öğrencilerin süreksiz metin okuma becerilerini anlamlı düzeyde etkilemesidir. Bu katkının hangi açılardan olduğunu incelemek için nitel bulgulara baktığımızda en dikkat çekici etkinin diğer dersleri anlama becerisinin gelişmesi üzerindedir. Öğrencilerin fen bilimleri ve matematik derslerini anlama becerilerin geliştiği bulgusuna ulaşılmıştır. Donolato, Giofrè ve Mammarella (2019), yaptıkları çalışmada matematik ve okuma becerileri arasında pozitif anlamlı ilişki olduğu sonucuna ulaşmıştır. Durgun ve Önder (2019), okuduğunu anlama, grafik okuma ve problem çözme becerisi öz denetim alt boyutunun Fen Bilimleri başarısının yordayıcıları oldukları görülmüştür. Yazar, sonuç olarak problem karşısında kendisini yönetebilen, okuduğunu anlama ve grafik okuma becerileri yüksek olan öğrencilerin fen bilimleri ve matematik dersinde başarılı oldukları çıkarımında bulunmuştur. Dolapçıoğlu (2019), düşünen sınıf ortamının ortaokul öğrencilerinin akademik başarı düzeyi yüksek ya da düşük tüm derslerinde etkili olduğu sonucuna ulaşmıştır. Bu sonuçlar çalışmanın bulgularını desteklemektedir.

Gerçek hayat içerik bağlantısı ile oluşturulan düşünen sınıf materyallerinin öğrencilerin ilgilerini çektiği ve okumaya ilgi duymaya başladıkları sonucuna ulaşılmıştır. Ören ve ark. (2017), yaptıkları çalışmada Türkçe öğretim programlarında öyküleyici, bilgilendirici, betimleyici, tartışmacı metin türlerine yer verildiğini ancak PISA'daki metinlerle karşılaştırıldığında günlük hayata daha az dönük ve daha az detaylı olduğu sonucuna ulaşmıştır. Çarkıt (2019), araştırmada 8. Sınıf Türkçe dersi kitabını öğrencilerin ilgisini çekmemesi, güncel konuları içermemesi, tema değerlendirmelerinin basit olması ve görsel içeriklerin zengin olmaması yönünden olumsuz bulmaktadır. Güneş’ e göre (2013), eğer dil öğretim sürecinde öğrenciye metin, konu, etkinlik kişisel ilgi ve merakları ile ilişkilendirilirse dilin işlenmesi daha hızlı olur ve öğrenilen becerilerin kalıcılığı artar. Özgün metinlerin dil öğretiminde çok yararlı olduğu vurgulanmıştır. Oysa kitaplarda eleştirel okuma, metinlerle ilişkilendirme, soru sorarak okuma yöntem ve tekniklerine ise hiç yer verilmediği tespit edilmiştir. Bu sebeple Türkçe kitaplarındaki metinler gözden geçirilerek, DSM olarak yeni metinlere kitaplarda yer verilebilir. Çünkü yapılan araştırmalar, okullarda materyallerin çok uyaranlı öğrenme ortamı yaratma konusunda yeterli olmadığı (Göçer ve Akgül, 2019) ve Türkçe ders kitabı metin sorularının çoğunluğunun $(\% 66,8)$ basit anlama düzeyinde sorular içerdiğini vurgulamaktadır (Sezgin ve Özilhan, 2019).

Aksu ve Sellüm (2019), Hong Kong'un Temel Eğitim Program Kılavuzunu incelenmiştir. PISA okuma bölümü başarılarını bu kılavuz ile karşılaştırmıştır. Araştırma sonuçları tüm okul yaklaşımıyla okuma performansının geliştirilmesinde okul yöneticilerine, okul programı geliştirme uzmanlarına, öğretmen kütüphanecilere, öğretmenlere, ebeveynlere ve öğrencilere sorumluluk ve görevler düştüğü göstermektedir. O hâlde okuma bir kültürel problemdir ve okuma kültürünü geliştirici sosyal çalışmalar yapılması önerilebilir. Ayrıca ana dili gelişimi önündeki kültürel bir engel de teknolojinin fazla kullanılmasıdır. Bilgisayar, tablet akılı telefonlar çıktığından bu yana insanlar okumaya çok az zaman harcanması ana dili değerlendirme düzeyinde anlamayı engelleyen ögelerden biri olarak görülebilir. Birkaç istisna dışında ekranlar kitapların yerini almaktadır. Otururken, yürürken veya arkadaşları ile bir aradayken akıllı telefon ile uğraşmayan bir öğrenci görmek imkânsız hâle gelmiştir (Tomlinson, 2012; Venugopalan, 2019). Okuma oranının düşmesi doğrudan yazılı metinlerin anlaşılma düzeyini olumsuz etkileyebilecek bir bulgudur. PISA 2012 ve PISA 2015 için anlamlı bir şekilde yordayan okul düzeyi değişkenlerinin bilgisayar kullanılabilirlik endeksi olduğu düşünüldügünde (Ötken, 2019) buradaki ifadenin teknolojik-okuryazarlık becerisi ile ilgili olmadığı açıktır. Bugün kişi başına gelir düzeyi en yüksek ülkelerden Amerika'nın bile PISA başarısının dünya ülke ortalamasının altında olması çok garip ve doğrudan ana dili anlamanın sosyo-ekonomik bir sorun değil kültürel bir okuma sorunu olarak yorumlanmasını sağlayabilir (Venugopalen, 2019). Bu durumda Türkiye'nin uluslararası sınavlarda (PISA, PIRLS, TIMMS) üst düzey başarıya sahip olmaması şaşırtıcı bir durum olarak görülmemelidir. 
Demir ve Demirtaşlı (2014) PISA 2003-2006-2009 dönemlerindeki okuma becerilerini yordayan en önemli sosyoekonomik ve kültürel değişkenlerin sırasıyla evdeki eğitim kaynakları, anne ve babanın eğitim durumu ve kültürel olanaklar olduğu sonucuna ulaşmıştır.

Düşünme becerileri gelişimi matematik-fen bilimleri başta olmak üzere tüm ders öğretim programları ana yeterlilik alanı olan ana dili geliştirme başta olmak üzere birçok alanda önemlidir. Bu sebeplerden dolayı materyal geliştirme ekipleri kurularak düşünen sınıf materyalleri her alanda üretilmeli ve öğretmenler kullanımı için bilinçlendirilmelidir. Ayrıca mevcut kullanılan materyaller düşünen sınıf özelliklerini ve DSM ilkelerini içermesi boyutlarında değerlendirmelidir.

\section{Kaynaklar}

Aksu, D., ve Sellüm, F. S. (2019). Improving reading performance through the whole school approach: the sample of Hong Kong. Tüm okul yaklaşımıyla okuma performansının artırılması: Hong Kong örneği. Journal of Human Sciences, 16(1), 270-284.

Anderson, Lorin W., and David R. Krathwohl (Eds.). 2001. A taxonomy for learning, teaching and assessing: A revision of Bloom's Taxonomy of educational objectives. Boston, MA: Person Educational Group.

Bozkurt, B. Ü. (2016). Türkiye'de okuma eğitiminin karnesi: PISA ölçeğinden çıkarımlar. Abant İzzet Baysal Üniversitesi Eğitim Fakültesi Dergisi, 16(4).

Cheung, D. (2000). Measuring teachers' meta-orientations to curriculum: Application of hierarchical confirmatory factor analysis. The Journal of experimental education, 68(2), 149-165.

Çarkıt, C. (2019). 2018 Türkçe dersi öğretim programı çerçevesinde hazırlanan 8. sınıf türkçe ders kitabının değerlendirilmesi. Electronic Journal of Social Sciences, 18(71).

Demir, S. B., ve Demirtaşlı, N. (2014). Türk öğrencilerinin PISA 2003-2006-2009 dönemlerindeki okuma becerilerini yordayan sosyoekonomik ve kültürel değişkenlerin araştırılması. Ankara Üniversitesi Eğitim Bilimleri Fakültesi Dergisi, 47(2), 201-222.

Doğanay, A. (2017). Üst düzey düşünme becerilerinin öğretimi. İçinde A. Doğanay (Ed.), Öğretim ilke ve yöntemleri (s. 328-380). Ankara: Pegem A.

Doğanay, A., ve Sarı, M. (2012). A Study of Developing the Thinking-Friendly Classroom Scale (TFCS). Elementary Education Online, 11(1), 214-229.

Dolapçıoğlu, S. (2019). Teacher Support for a Classroom Setting that Promotes Thinking Skills: An Analysis on the Level of Academic Achievement of Middle School Students. Çukurova Üniversitesi Eğitim Fakültesi Dergisi, 48(2), 1429-1454.

Donolato, E., Giofre, D., ve Mammarella, I. C. (2019). Working memory, negative affect and personal assets: How do they relate to mathematics and reading literacy?. PloS one, 14(6).

Durgun, E., ve Önder, İ. (2019). Ortaokul 7. Sınıf Öğrencilerinin Fen Bilimleri Başarıları ile Okuduğunu Anlama, Grafik Okuma ve Problem Çözme Becerileri Arasındaki ilişki. Journal of Individual Differences in Education, 1(1), 1-13.

Echeverri Acosta, L. M., ve McNulty Ferri, M. (2010). Reading strategies to develop higher thinking skills for reading comprehension. Profile Issues in TeachersProfessional Development, 12(1), 107-123.

Fisher, R. (2001). Philosophy in primary schools: fostering thinking skills and literacy. Reading, 35(2), 67-73.

Furst, S. (2019). The Impact of Teaching Students Higher Order Thinking Skills on Reading Comprehension.

Göçer, A., ve Akgül, O. (2019). Türkçe öğretmenlerinin dil eğitiminde ortam tasarımı ve materyal kullanımı yeterliklerinin değerlendirilmesi. Bingöl Üniversitesi Sosyal Bilimler Enstitüsü Dergisi, 9(18), 837-856.

Güneş, F. (2013a). Türkçe öğretiminde metin seçimi. Ana Dili Eğitimi Dergisi, 1(1), 1-12.

Haladyna, T. M. (1997). Writing Test Items To Evaluate Higher Order Thinking. Allyn ve Bacon, 160 Gould Street, Needham Heights, MA 02194-2310. 
Hasan, B. 2019. "The exploration of higher order thinking skills: students' difficulties and scaffolding in solving mathematical problems based on PISA." Journal of Physics: Conference Series 1200 (1): 012010. doi: 10.1088/1742-6596/1200/1/012010.

Huizinga, T., Handelzalts, A., Nieveen, N., ve Voogt, J. M. (2014). Teacher involvement in curriculum design: Need for support to enhance teachers' design expertise. Journal of curriculum studies, 46(1), 33-57.

Ichsan, I. Z., Sigit, D. V., ve Miarsyah, M. (2019). Environmental Learning based on Higher Order Thinking Skills: A Needs Assessment. International Journal for Educational and Vocational Studies, 1(1), 21-24.

İşeri, A. (2019). Uluslararası PISA yeterlikleri ve türkiye öğretim programları kazanımları. Mersin Üniversitesi Eğitim Fakültesi Dergisi. 15(2), 392-418.

Jerome, C., J. L. A. Cheng, and T. S. Hie. 2019. “Undergraduate Students' and Lecturers' Perceptions on Teaching Strategies that Could Enhance Higher Order Thinking Skills (HOTS)." International Journal of Education 4 (30): 60-70.

Karadüz, A. (2010). Dil becerileri ve eleştirel düşünme. Turkish Studies, 5(3), 1566-1593.

Kerr, S. T. (1981). How teachers design their materials: Implications for instructional design. Instructional Science, 10(4), 363-378.

Koç, C. (2011). Aktif öğrenmenin okuduğunu anlama ve eleştirel düşünme üzerindeki etkileri. Cumhuriyet Üniversitesi Edebiyat Fakültesi Sosyal Bilimler Dergisi, 35(1), 28-37.

Kucan, L.,ve Beck, I. L. (1997). Thinking aloud and reading comprehension research: Inquiry, instruction, and social interaction. Review of educational research, 67(3), 271-299.

Kusumastuti, I., E. Fauziati, and S. Marmanto. 2019. "Revealing Teachers' Beliefs of Higher Order Thinking Skills in Teaching Reading at Junior High School." Paper presented at the English Language and Literature International Conference (ELLiC) Proceedings, May, Vol. 3, 155-162.

Lei, Y., Wen, Z., Li, J., Kong, Y., Chen, Q., ve Li, S. (2019). Teacher Support, Reading Strategy and Reading Literacy: A Two-Level Mediation Model. Best Evid Chin Edu, 2(1), 157-170.

Marzano, R. J. (2017). The new art and science of teaching. Bloomington: Solution Tree Press.

MEB (2015), Ölçme, Değerlendirme Ve Sınav Hizmetleri Genel Müdürlüğü, Uluslararası Öğrenci Başarılarını Değerlendirme Programı, PISA Örnek Okuma Becerileri Soruları. Ankara.

Menggo, S., Suastra, I., Budiarsa, M., ve Padmadewi, N. N. (2019). Needs Analysis of Academic-English Speaking Material in Promoting 21st Century Skills. International Journal of Instruction, 12(2), 739-754.

Miri, Barak, Ben-Chaim David, and Zoller Uri. 2007. "Purposely teaching for the promotion of higherorder thinking skills: A case of critical thinking." Research in Science Education 37 (4): 353-369. doi: 10.1007/s11165-006-9029-2.

Newmann, F. M. (1990). Qualities of thoughtful social studies classes: An empirical profile. Journal of Curriculum Studies, 22(3), 253-275.

Newmann, F.M. ve Weglage, G.G.(1993). Five standarts for authentic instruction. Educational Leadership, 50(7),8-12.

OECD. 2015. "PISA 2015, PISA Results in Focus. Better Policies for Better Lives." OECD. Accessed May 12, 2019. https://www.oecd.org/pisa/pisa-2015-results-in-focus.pdf.

Ören, Z., Konuk, S., Sefer, A., ve Sarıtaş, H. (2017). Ortaokul Türkçe öğretim programlarındaki metin türleri ile PISA'daki metin türlerinin karşılaştırılması. In EJER IV. Internatıonal Eurasıan Educatıonal Research Congress Bildiri Kitabı (Vol. 275280).

Ötken, Ş. (2019). PISA Uygulamalarında Okuma-Matematik-Fen Okuryazarlığı Puanlarındaki Değişimin Çok Değişkenli-Çok Düzeyli Model ille İncelenmesi, yayınlanmamış doktora tezi, Hacettepe üniversitesi.

Ramos, J. L. S., B. B. Dolipas, and B. B. Villamor. 2013. "Higher order thinking skills and academic performance in physics of college students: A regression analysis." International Journal of Innovative Interdisciplinary Research 4 (1): 48-60.

Ritchhart, R. (2002). Intellectual character: What it is, why it matters and how to get it. San Fransisco: Jossey-Bass. 
Sammons, L. (2011). Building mathematical comprehension: Using literacy strategies to make meaning. Teacher Created Materials.

Schröter, H., ve Bar-Kochva, I. (2019). Keyword: Reading literacy. Reading competencies in Germany and underlying cognitive skills. Zeitschrift für Erziehungswissenschaft, 22(1), 17-49.

Sezgin, Z. Ç., ve Özilhan, Y. G. G. (2019). 1.-8. Sınıf Türkçe Ders Kitaplarındaki Metne Dayalı Anlama Sorularının İncelenmesi. Ana Dili Eğitimi Dergisi, 7(2), 353-367.

Steer, D., Iverson, E. R., Egger, A. E., Kastens, K. A., Manduca, C. A., ve McConnell, D. (2019). The InTeGrate materials development rubric: a framework and process for developing curricular materials that meet ambitious goals. In Interdisciplinary teaching about earth and the environment for a sustainable future (pp. 25-43). Springer, Cham.

Şahin, N., ve Sarı, M. (2016). Investigation of Educational Environments in Secondary Schools in Terms of Thinking Friendly Classroom Characteristics. Kuram ve Uygulamada Egitim Yönetimi Dergisi, 22(4), 565-592.

Tavsancil, E., Yildirim, O., ve DEMIR, S. B. (2019). Direct and Indirect effects of learning strategies and reading enjoyment on PISA 2009 reading performance. Eurasian Journal of Educational Research, 19(82), 169-190.

Thamrin, N. R., ve Agustin, S. (2019). Conceptual varıatıons on readıng comprehensıon through higher order thınkıng skılls (HOTS) Strategy. English Review: Journal of English Education, 7(2), 93-100.

Tomlinson, B. (2012). Materials development for language learning and teaching. Language teaching, 45(2), 143-179.

Tuzlukaya, S. (2019). 8. Sınıf türkçe dersi merkezî sınav sorularının PISA okuma becerileri yeterlilikleri açısından incelenmesi. The Journal of International Lingual Social and Educational Sciences, 5(1), 92-100.

Udall, A. J. ve Daniels, J. E. (1991). Creating active thinkers: 9 strategies for a thoughtful classroom. Chicago: Zephyr Pres.

Uysal, M. E. (2009). İlköğretim Türkçe dersinde işbirlikli öğrenmenin erişi, eleştirel düşünce ve yaratıcılık becerilerine etkisi (Doctoral dissertation, DEÜ Eğitim Bilimleri Enstitüsü).

Venugopalan, M. 2019. "Building Critical Thinking Skills through Literature." In International Forum of Teaching and Studies 15 (1): 38-44. Toronto: American Scholars Press, Inc.

Yaşar, Ö. Ü. F. Ö. (2019). 2018 Türkçe Dersi Öğretim Programına Göre Hazırlanmış 7. Sınıf Türkçe Ders Kitaplarındaki Metinlerin Okuma Yöntem ve Teknikleri Açısından İncelenmesi. Cataloging-InPublication Data, 326.

Yüce, S. G. (2012). Bir ilköğretim okulunda düşünme kültürünün geliştirilmesine yönelik eylem araştırması (Yayımlanmamış doktora tezi). Çukurova Üniversitesi, Adana.

\section{Extended Abstract \\ Introduction}

MTC are two-dimensional materials including learning models for creating thinking classroom environment and developing thinking skills. Thinking classroom environment requires teacher support, teacher-student relationship and communication-based teacher activities. These components, beyond basic remembering in classroom, can be listed as providing activities which boost meaningful thinking, encouraging students to take active roles in these activities and allowing response time to questions. On the other side, activities such as listening to students carefully and creating a comfortable classroom environment in which students express their opinions freely are presented in a classroom where thinking is learnt (Doğanay and Sarı, 2012; Dolapçıŏlu, 2019; Udall and Daniels, 1991). One of the most important signs showing that teaching practices in schools regarding understanding native language do not focus on the concern of supporting thinking skills anymore is the Turkey's score on PISA international reading skills (OECD, 2015). Besides, although special and authentic text types suitable to new approaches are given place in books (Güneş, 2013), there are some on-going discussions at national level about understanding native language which claim that the social 
environment based on comprehension and narration activities are insufficient in studies towards classroom evaluation in Turkish lesson in general (Karadüz, 2010) and that the materials and designs teachers use fail to create stimulus-rich environment for students and stories, novels and poems are used instead (Göçer and Akgül, 2019). Lastly intertextual and interdisciplinary connections are left to the knowledge-skills of teacher without enough guide in the syllabus (Karatay, 2010). Aim of this study is to fill this gap in this sense. Students should have education with MTC which enables a classroom equipped with thinking classroom facilities in order to examine written texts at analysis and evaluation level. Therefore, following questions were tried to be answered in purpose of the effect of MTC in understanding PISA text types at evaluation level:

1) Is there a significant difference between pretest and posttest scores in terms of understanding continuous texts for the experimental group students in the classrooms where practices based on materials for thinking classroom were conducted?

2) Is there a significant difference between pretest and posttest scores in terms of understanding discontinuous texts for the experimental group students in the classrooms where practices based on materials for thinking classroom were conducted?

3) Is there a significant difference between pretest and posttest scores in terms of PISA reading skills for the experimental group students in the classrooms where practices based on materials for thinking classroom were conducted?

4) What are the contributions of thinking materials and using them as thinking classroom learning model to comprehension of reading texts?

\section{Method}

Convergent parallel design method was used in the research. Quantitative aspect of the research was designed as convergent parallel design and according to pre-test post-test control group design of experimental research models. Interview method was used for the qualitative aspect. Continuous-discontinuous text reading comprehension test and interview questions were used as data collection tools.

\section{Results}

MTC improved student achievement in a significant way in terms of understanding continuous texts. When the qualitative findings were examined, it was found that the students' academic success increased, their skills of getting the gist in the text, discovering main clauses and sub-clauses in the text and reading and understanding paragraph related questions improved. Another finding acquired in the study was that materials for thinking classroom affected discontinuous text reading skills of students significantly. It was found out that the most remarkable effect was the increased skill of understanding other subjects. Another important finding was that MTC improved evidence-providing skills. Evidenceproviding is an important development in PISA exam achievement for evaluation and analysis steps which includes critical thinking skills. The most important difference of materials for thinking classroom from current classroom materials lies in its thinking classroom-supported structure. This structure improved the experimental group students' social in-classroom support and understanding through peer-listening. Materials for thinking classroom which are created with real-life connections were found to be attractive for students and increased interest on reading. Development of thinking skills is very important in many fields starting with math and science, to all fields. For this reason, activities on Turkish syllabus should be examined and they should be developed based on MTC principles. 